\title{
INTERLANGUAGE PRAGMATICS IN TURKISH
}

\section{Mehmet Kanık}

\begin{abstract}
This study aims to investigate interlanguage pragmatics in Turkish. For this purpose, a discourse completion questionnaire including four request situations was given to 33 learners of Turkish at a university in Istanbul, Turkey as well as 45 Turkish native speakers in two different programs at the same institution. The data were then coded into request strategies. The length of requests and the number of strategies employed were also coded. The request strategies were analyzed using the chi-square test while the length and the number of strategies were analyzed using the independent samples t-test. Results indicate that the two groups differed in head act strategies and downgrader strategies only in situation 3 while they differed in situation 2 through 4 in using supportive moves. In the length of the requests, number of supportive moves and the number of downgraders, the groups differed in only one situation. This shows that although differences are observed, there is no drastic difference between native-Turkish speaking students and learners of Turkish as a second language. This shows that even after one academic year in the target speech community, learners tend to choose strategies similar to the native speakers of the target language. The effect of sojourn in the target community could be further researched by comparing learners of Turkish in the target speech community to those that learn Turkish outside of the target speech community after the same amount of time spent learning Turkish..
\end{abstract}

Key words: Interlanguage pragmatics, requests, Turkish, study abroad. 


\title{
TÜRKÇEDE DÍLLER ARASI EDIMMBILIIM
}

\begin{abstract}
$\ddot{\text { Ozet }}$
Bu çalışmada Türkçede aradil edimini araştırmak amaçlanmıştır. Bu amaçla, dört durumdan oluşan bir söylem tamamlama testi İstanbul'da bulunan bir üniversitede yabancı dil olarak Türkçe ögrenen 33 yabancı öğrenciye verilmiştir. Yine aynı üniversitedeki iki programda kayıtlı 45 Türk öğrencinin verileri de kullanılmıştır. Elde edilen veriler kodlanarak rica stratejilerine ayrılmıştır ve bu stratejiler ki-kare testiyle incelenmiştir. Bunun yanında her rica için kullanılan kelime sayısı ve strateji sayıları da kodlanarak bağımsız örneklem t-testiyle incelenmiştir. Sonuçlara göre iki grup arasında rica ana eylem stratejisinde ve derece düşürücü stratejilerde yalnızca 3. durumda anlamlı farklılık gözlenmiştir. Bununla birlikte, destekleme stratejilerinde ikinci, üçüncü ve dördüncü durumlarda anlamll farklılık gözlenmiştir. Kullanılan ricaların uzunluklarına ve kullanılan strateji sayılarına göre karşılaştırıldıklarında, iki grup arasında birer durumda anlamlı farklılık tespit edilmiştir. Bu durum, her ne kadar anlamlı farklılıklar gözlemlenmiş olsa da iki grup arasındaki farklılı̆̆ın büyük olmadı̆̆ını göstermektedir. Aynı zamanda, bu durum, hedef dilin konuşulduğu toplumda geçirilen yalnızca bir akademik yıl sonunda, dili ögrenenlerin ana dil konuşucularına benzer stratejileri seçebildiklerini göstermektedir. Hedef dilin konuşulduğu toplumda bir süre kalmanın dil gelişimine etkisi hedef dili konuşulduğu toplumda ögrenenlerle o toplum dışında ögrenenleri kıyaslamayla daha derinlemesine araştırılabilir.
\end{abstract}

Anahtar Kelimeler: Aradil edimi, rica, Türkçe, yurtdışında eğitim. 


\section{INTRODUCTION}

The study of pragmatics traces back to the works of philosophers in 1960's and 1970's like Austin (1962), Searle (1969; 1979) and Grice (1975). The area developed in two directions one being speech acts, the other being conversational implicatures following the works of these philosophers. However, in the area of pragmatics research, the focus has mainly been on speech acts (Cohen, 2004). When it came to 1980 's, studies in the cross-cultural pragmatics focusing on different speech acts emerged (e.g. Blum-Kulka, 1982, Cohen \& Olshtain, 1981). The comprehensive Cross-Cultural Study of Speech Act Realization Patterns (CCSARP) became a driving force as it provided a framework for analysis of speech acts (Blum-Kulka \& Olshtain, 1984; Blum-Kulka, House \& Kasper, 1989). Following those initial works in the area, attempts to describe speech acts in different languages followed. Although English accounts for the bulk of research in the area, there are quite a few studies in languages like Spanish (Félix-Brasdefer, 2009; García, 1993), Japanese (Fukushima, 1996), Chinese (Hong, 1996), Korean (Byon, 2004; Byon, 2006; Rue, Zhang \& Shin, 2007) and Hebrew (Blum-Kulka, Danet \& Gherson, 1985). However, research on Turkish requests is very scarce. A few studies focused on Turkish request with a crosslinguistic transfer perspective (e.g. Marti, 2006; Kanik, 2010).

Following the model put forward by the research in cross-cultural pragmatics, attempts to describe learners' pragmatic development gave way to a field called interlanguage pragmatics (ILP) (Kasper \& Schmidt, 1996), which is defined as nonnative speakers' use and acquisition of pragmatic knowledge in the target language (Kasper \& Dahl, 1991; Kasper \& Rose, 1999). Most research in this area, however, is comparative rather than developmental. Developmental aspect of interlanguage pragmatics is represented in Kasper and Schimdt's (1996, p. 150) definition, "the study of the development and use of strategies for linguistic action by nonnative speakers." Bardovi-Harlig (1999) criticizes the studies in interlanguage pragmatics as she claims they actually lack interlanguage focus of second language acquisition. Rather than being longitudinal or cross-sectional studies of acquisition or development of L2 pragmatic knowledge, the bulk of the studies are comparative. Kasper and Schmidt (1996, p. 150) also say "ILP has thus been primarily a study of second language use rather than second language learning" as much attention has been given to how pragmalinguistic and sociopragmatic knowledge of nonnative speaker differ from native speakers.

Because of this duality, Rose (2000) makes a distinction between interlanguage pragmatics research and interlanguage pragmatic development research. He says there are a good number of pragmatic performance studies in interlanguage pragmatic research but only a handful of developmental studies are available in interlanguage pragmatic research studies. 
As mentioned above, interlanguage pragmatics used the model developed in crosscultural pragmatics, thus research in interlanguage pragmatics turned out to be comparative like in cross-cultural pragmatics research. The current study does not claim to be a developmental study in interlanguage pragmatics. Rather it is, in Rose's (2000) terms, an interlanguage pragmatics study. In particular, this study describes pragmatic use of learners of Turkish as a second language (TSL) in the target speech community as compared to native speakers of Turkish. As noted by several researchers (e.g. Barron, 2003, Cohen, 2004) pragmatics does not receive enough attention in teaching curricula and practice. Also, it is claimed that even in teaching of English, which is described much more than any other language, learning pragmatics from textbooks is not likely to happen (Vellenga, 2004). On the other hand, Barron $(2003$, p. 2) says, "time spent in the target speech community remains a primary opportunity for language learners to acquire L2 pragmatic competence due to the accessibility of authentic pragmatic input in the target speech community." When Turkish is considered, descriptions of pragmatics of Turkish is very scarce. Thus, expecting learning of pragmatics in the classroom or from the textbook would not be realistic. This study aims to investigate whether acquisition of pragmatics occurs in the target speech community in an interlanguage pragmatics perspective. Since this study does not control for the native languages of learners, participants are chosen from different linguistic backgrounds to minimize the effect of crosslinguistic transfer by employing learners with different first languages.

\section{METHODS}

The data was collected using a discourse completion test including four request situations in Turkish. These situations were created based on three sociopragmatic variables of relative power of speaker to hearer, distance between speaker and hearer and the absolute ranking of imposition (Brown and Levinson, 1987; Hudson, Detmer and Brown, 1995). Only situations with high imposition are used. The other two variables are ranked either high or low and thus naturally distribute to four situations based on their rating. Neutral rankings were not used (see table 1 below).

Table 1: Situations

\begin{tabular}{llll}
\hline & Speaker & Hearer & Request \\
\hline Situation 1 & A human resources manager & An applicant & $\begin{array}{l}\text { Come again next week for } \\
\text { a second interview }\end{array}$ \\
\hline Situation 2 & A manager in a factory & A worker & Work overtime \\
\hline Situation 3 & An employee in a restaurant & A customer & Move to another table \\
\hline Situation 4 & A college student & A professor & Extend deadline for a project \\
\hline
\end{tabular}


The four situations were given to 33 learners of Turkish at a university in Istanbul, Turkey. These students came from 16 different countries. Eighteen of them were male and 15 of them were female. The mean age of the participants in TSL group is 24.73. These students took the questionnaire within the last month of their first academic year in the target speech community. Their data is compared to 45 native speaking seniors from Turkish language teaching and social science teaching programs at the same university. Of the students in the native speaking group, 18 were male and 27 were female. Their mean age is 22.89 . Tables 2 through 4 show participants' profiles.

Table 2: Nonnative speaking participants' countries of origin

\begin{tabular}{cc}
\hline Countries of Origin & Number \\
\hline Afghanistan & 1 \\
Brazil & 1 \\
Bulgaria & 1 \\
China & 11 \\
England & 1 \\
Georgia & 2 \\
Iran & 3 \\
Korea & 1 \\
Morocco & 1 \\
Nigeria & 5 \\
Peru & 1 \\
Russia & 1 \\
Syria & 1 \\
Taiwan & 1 \\
Turkmenistan & 1 \\
Yemen & 1 \\
\hline
\end{tabular}

Table 3: Participants' gender

\begin{tabular}{llllll}
\hline & & \multicolumn{3}{c}{ Group } \\
\cline { 3 - 5 } & & Turkish & TSL & Total \\
\hline \multirow{2}{*}{ Gender } & Male & Count & 18 & 18 & 36 \\
& & \% within Program & $40.0 \%$ & $54.5 \%$ & $46.2 \%$ \\
\cline { 2 - 5 } & Female & Count & 27 & 15 & 42 \\
& & \% within Program & $60.0 \%$ & $45.5 \%$ & $53.8 \%$ \\
\hline Total & Count & 45 & 33 & 78 \\
& & \% within Program & $100.0 \%$ & $100.0 \%$ & $100.0 \%$ \\
\hline
\end{tabular}


Table 4: Participants' age

\begin{tabular}{lllllll}
\hline Program & Mean & $\mathrm{N}$ & Median & Minimum & Maximum & Range \\
\hline Turkish & 22.89 & 45 & 22.00 & 20 & 30 & 10 \\
TSL & 24.73 & 33 & 23.00 & 19 & 45 & 26 \\
Total & 23.68 & 78 & 23.00 & 19 & 45 & 26 \\
\hline
\end{tabular}

Requests from two groups were coded into request strategies in categories of head act, supportive moves and downgraders based on the coding manuals in BlumKulka, House and Kasper (1989) and Hudson, Detmer and Brown (1995). The strategies were then analyzed with chi-square test. The number of words and the number of strategies were analyzed with t-test. SPSS (Statistical Package for the Social Sciences) program was used for analyses.

\section{RESULTS}

Table 5: Distribution of strategies in head act in situation 1

\begin{tabular}{llll}
\hline & & \multicolumn{2}{c}{ Group } \\
\cline { 3 - 4 } & & Turkish & TSL \\
\hline \multirow{2}{*}{ S1HeadAct } & $\mathrm{N}(\%)$ & $\mathrm{N}(\%)$ \\
\cline { 2 - 4 } & Mood derivable & $2(4)$ & $3(8.8)$ \\
\cline { 2 - 4 } & Statement of fact & $6(12)$ & $3(8.8)$ \\
\cline { 2 - 4 } & Explicit performative & $6(12)$ & $9(26.5)$ \\
\cline { 2 - 4 } & Locution derivable & $11(22)$ & $7(20.6)$ \\
\cline { 2 - 4 } & Want statement & $10(20)$ & $5(14.7)$ \\
\cline { 2 - 4 } & Preparatory & $13(26)$ & $6(17.6)$ \\
\cline { 2 - 4 } & Strong hint & $50(100)$ & $34(100)$ \\
\hline Total & &
\end{tabular}

$\left(\chi^{2}(6, N=78)=4.379, p>.05, p=.626\right)$

Table 5 shows the frequency of head acts used by the two groups of students in situation 1 . The distribution of these items does not result in a significant difference, $\chi^{2}(6, N=78)=4.379, p>.05$. 
Table 6: Distribution of strategies in head act in situation 2

\begin{tabular}{|c|c|c|c|}
\hline & & \multicolumn{2}{|c|}{ Group } \\
\hline & & Turkish & TSL \\
\hline & & $\mathrm{N}(\%)$ & $\mathrm{N}(\%)$ \\
\hline \multirow[t]{8}{*}{ S2HeadAct } & Mood derivable & $3(6.2)$ & $0(0)$ \\
\hline & Statement of fact & $7(14.6)$ & $5(14.3)$ \\
\hline & Explicit performative & $5(10.4)$ & $8(22.9)$ \\
\hline & Locution derivable & $7(14.6)$ & $8(22.9)$ \\
\hline & Want statement & $9(18.8)$ & $2(5.7)$ \\
\hline & Suggestory formula & $0(0)$ & $1(2.9)$ \\
\hline & Preparatory & $15(31.2)$ & $9(25.7)$ \\
\hline & Strong hint & $2(4.2)$ & $2(5.7)$ \\
\hline Total & & $48(100)$ & $35(100)$ \\
\hline
\end{tabular}

According to Table 6, which shows the frequency of head acts used by the two groups of students in situation 2, the distribution does not result in a significant difference, $\chi^{2}(7, N=78)=9.237, p>.05$.

Table 7: Distribution of strategies in head act in situation 3

\begin{tabular}{llll}
\hline & & \multicolumn{2}{c}{ Group } \\
\cline { 2 - 4 } & & Turkish & TSL \\
\hline \multirow{2}{*}{ S3HeadAct } & Mood derivable & N $(\%)$ & $1(3)$ \\
\cline { 2 - 4 } & Statement of fact & $1(2.2)$ & $6(18.2)$ \\
\cline { 2 - 4 } & Explicit performative & $0(0)$ & $4(12.1)$ \\
\cline { 2 - 4 } & Locution derivable & $5(11.1)$ & $4(12.1)$ \\
\cline { 2 - 4 } & Want statement & $2(4.4)$ & $1(3)$ \\
\cline { 2 - 4 } & Suggestory formula & $0(0)$ & $13(6.1)$ \\
\cline { 2 - 4 } & Preparatory & $31(68.9)$ & $1(3)$ \\
\cline { 2 - 4 } & Strong hint & $2(4.4)$ & $3(6.7)$ \\
\cline { 2 - 4 } & Turkish desiderative & $45(100)$ & $1(100)$ \\
\hline Total & &
\end{tabular}

$\left(\chi^{2}(7, N=78)=9.237, p>.05, p=.236\right)$

Significant difference is observed in head act strategies in situation $3, \chi^{2}(8, N=78)$ $=17.276, p<.05$. Table 7 outlines the frequency of head acts used by the two groups of students in this situation. 
Table 8: Distribution of strategies in head act in situation 4

\begin{tabular}{llll}
\hline & & \multicolumn{2}{c}{ Group } \\
\cline { 3 - 4 } & & Turkish & TSL \\
& & $\mathrm{N}(\%)$ & $\mathrm{N}(\%)$ \\
\hline \multirow{2}{*}{ S4HeadAct } & Mood derivable & $2(4.1)$ & $2(5.7)$ \\
\cline { 2 - 4 } & Statement of fact & $0(0)$ & $1(2.9)$ \\
\cline { 2 - 4 } & Explicit performative & $5(10.2)$ & $6(17.1)$ \\
\cline { 2 - 4 } & Locution derivable & $2(4.1)$ & $0(0)$ \\
\cline { 2 - 4 } & Want statement & $6(12.2)$ & $7(20)$ \\
\cline { 2 - 4 } & Preparatory & $30(61.2)$ & $18(51.4)$ \\
\cline { 2 - 4 } & Strong hint & $3(6.1)$ & $1(2.9)$ \\
\cline { 2 - 4 } & Turkish desiderative & $49(100)$ & $35(100)$ \\
\hline Total & & &
\end{tabular}

In situation 4 , no significant difference is observed, $\chi^{2}(7, N=78)=6.001, p>.05$. For both groups, preparatrory is the most frequent strategy employed in the head act of request in this situation.

Table 9: Distribution of supportive moves in situation 1

\begin{tabular}{llll}
\hline & & \multicolumn{3}{c}{ Group } \\
\cline { 2 - 4 } & & Turkish & TSL \\
& & $\mathrm{N}(\%)$ & $\mathrm{N}(\%)$ \\
\hline S1SupMove & Imposition minimizer & $5(7.3)$ & $12(20.3)$ \\
\cline { 2 - 4 } & Grounder & $36(52.9)$ & $25(42.4)$ \\
\cline { 2 - 4 } & Disarmer & $7(10.3)$ & $7(11.9)$ \\
\cline { 2 - 4 } & Preparator & $6(8.8)$ & $1(1.7)$ \\
\cline { 2 - 4 } & Apology & $1(1.5)$ & $5(8.5)$ \\
\cline { 2 - 4 } & Gratitude & $9(13.2)$ & $5(8.5)$ \\
\cline { 2 - 4 } & Promise of reward & $2(2.9)$ & $3(1.7)$ \\
\cline { 2 - 4 } & Promise & $68(100)$ & $59(100)$ \\
\hline Total & & &
\end{tabular}

$\left(\chi^{2}(7, \mathrm{~N}=78)=12.204, \mathrm{p}>.05, \mathrm{p}=.094\right)$

Table 9 shows the frequency of supportive moves used by the two groups of students in situation 1 . The distribution of these items does not result in a significant difference, $\chi^{2}(7, N=78)=12.204, p>.05$. 
Table 10: Distribution of supportive moves in situation 2

\begin{tabular}{llll}
\hline & & \multicolumn{2}{c}{ Group } \\
\cline { 2 - 4 } & & Turkish & TSL \\
& & $\mathrm{N}(\%)$ & $\mathrm{N}(\%)$ \\
\hline S2SupMove & Imposition minimizer & $0(0)$ & $1(2)$ \\
\cline { 2 - 4 } & Grounder & $41(75.9)$ & $25(49)$ \\
\cline { 2 - 4 } & Disarmer & $6(11.1)$ & $3(5.9)$ \\
\cline { 2 - 4 } & Preparator & $4(7.4)$ & $4(7.8)$ \\
\cline { 2 - 4 } & Getting pre-commitment & $0(0)$ & $1(2)$ \\
\cline { 2 - 4 } & Apology & $0(0)$ & $3(5.9)$ \\
\cline { 2 - 4 } & Gratitude & $0(0)$ & $1(13)$ \\
\cline { 2 - 4 } & Promise of reward & $1(1)$ & $1(2)$ \\
\cline { 2 - 4 } & Threat & $0(0)$ & $51(100)$ \\
\cline { 2 - 4 } & Promise & $54(100)$ & \\
\hline Total & &
\end{tabular}

$\left(\chi^{2}(9, N=78)=18.586, p<.05, p=.029\right)$

In situation 2, however, significant difference is observed, $\chi^{2}(9, N=78)=18.586$, $p<.05$. As Table 10 reveals, there is more variability in the strategies employed by TSL group. Although the most frequent strategy for both groups is grounder, it accounts for $76 \%$ of supportive moves employed by Turkish native speakers while it accounts for only $49 \%$ of the supportive moves used by the TSL group in situation 2 .

Table 11: Distribution of supportive moves in situation 3

\begin{tabular}{llll}
\hline & & \multicolumn{2}{c}{ Group } \\
\cline { 2 - 4 } & & Turkish & TSL \\
& & $\mathrm{N}(\%)$ & $\mathrm{N}(\%)$ \\
\hline S3SupMove & Imposition minimizer & $1(1)$ & $10(12.7)$ \\
\cline { 2 - 4 } & Grounder & $39(39.4)$ & $24(30.4)$ \\
\cline { 2 - 4 } & Disarmer & $4(4)$ & $3(3.8)$ \\
\cline { 2 - 4 } & Preparator & $5(5.1)$ & $4(5.1)$ \\
\cline { 2 - 4 } & Apology & $27(27.3)$ & $26(32.9)$ \\
\cline { 2 - 4 } & Gratitude & $2(2)$ & $3(3.8)$ \\
\cline { 2 - 4 } & Promise of reward & $10(10.1)$ & $11(11.1)$ \\
\cline { 2 - 4 } & Threat & $0(0)$ & $79(1.3)$ \\
\cline { 2 - 4 } & Promise & $99(100)$ & \\
\hline Total & & & \\
\hline$\left(\chi^{2}(8, \mathrm{~N}=78)=\right.$ & $21.656, \mathrm{p}<.05, \mathrm{p}=.006)$ &
\end{tabular}


Table 11 shows the frequency of supportive moves used by the two groups of students in situation 3. The distribution of these items results in a significant difference, $\chi^{2}(8, N=78)=21.656, p<.05$. For both groups, grounder and apology are the most frequent strategies in the category of supportive moves. However, threat is used by Turkish native speakers 11 times while it was not employed by TSL at all. By contrast, imposition minimizer is used by TSL group 10 times while it was used only once by the Turkish group.

Table 12: Distribution of supportive moves in situation 4

\begin{tabular}{llll}
\hline & & \multicolumn{2}{c}{ Group } \\
\cline { 2 - 4 } & & Turkish & TSL \\
& & $\mathrm{N}(\%)$ & $\mathrm{N}(\%)$ \\
\hline \multirow{2}{*}{ S4SupMove } & Imposition minimizer & $2(3.3)$ & $2(2.9)$ \\
\cline { 2 - 4 } & Grounder & $40(66.7)$ & $28(41.2)$ \\
\cline { 2 - 4 } & Disarmer & $8(13.3)$ & $6(8.8)$ \\
\cline { 2 - 4 } & Preparator & $2(3.3)$ & $7(10.3)$ \\
\cline { 2 - 4 } & Apology & $3(5)$ & $10(14.7)$ \\
\cline { 2 - 4 } & Gratitude & $0(0)$ & $5(7.4)$ \\
\cline { 2 - 4 } & Promise of reward & $1(1.7)$ & $9(1.5)$ \\
\cline { 2 - 4 } & Threat & $3(5)$ & $68(100)$ \\
\cline { 2 - 4 } & Promise & $60(100)$ & \\
\hline Total & & & \\
\hline$\left(\chi^{2}(8, \mathrm{~N}=78)=\right.$ & $17.519, \mathrm{p}<.05, \mathrm{p}=.025)$ &
\end{tabular}

Table 12 shows the frequency of supportive moves used by the two groups of students in situation 4. The distribution of these items results in a significant difference, $\chi^{2}(8, N=78)=17.519, p<.05$. The most frequent strategy for both groups is grounder. However, this strategy makes up $67 \%$ of the supportive moves offered by the Turkish group while it accounts for only $41 \%$ of the supportive moves used by the TSL group.

Table 13: Distribution of downgraders in situation 1

\begin{tabular}{llll}
\hline & & \multicolumn{2}{c}{ Group } \\
& & Turkish & TSL \\
S1Downgrader & Politeness marker & $\mathrm{N}(\%)$ & $\mathrm{N}(\%)$ \\
\cline { 2 - 4 } & Understater & $1(3.8)$ & $4(16)$ \\
\cline { 2 - 4 } & & $0(0)$ & $2(8)$ \\
\hline
\end{tabular}




\begin{tabular}{llll} 
& Subjectivizer & $3(11.5)$ & $1(4)$ \\
\cline { 2 - 4 } & Cajoler & $1(3.8)$ & $1(4)$ \\
\cline { 2 - 4 } & Appealer & $0(0)$ & $2(8)$ \\
\cline { 2 - 4 } & Word choice & $0(0)$ & $5(20)$ \\
\cline { 2 - 4 } & Verbal noun & $5(19.2)$ & $3(12)$ \\
\cline { 2 - 4 } & Conditional politeness & $5(19.2)$ & $3(12)$ \\
\cline { 2 - 4 } & Aspect & $4(15.4)$ & $3(12)$ \\
\cline { 2 - 4 } & Tense & $4(15.4)$ & $1(4)$ \\
\cline { 2 - 4 } & Conditional clause & $3(11.5)$ & $25(100)$ \\
\hline Total & & $26(100)$ & \\
\hline
\end{tabular}

$\left(\chi^{2}(10, N=78)=17.930, p>.05, p=.056\right)$

Table 13 shows the frequency of downgraders used by the two groups of students in situation 1. The distribution of these items does not result in a significant difference, $\chi^{2}(10, N=78)=17.930, p>.05$.

Table 14: Distribution of downgraders in situation 2

\begin{tabular}{llll}
\hline & & \multicolumn{2}{c}{ Group } \\
\cline { 2 - 4 } & & Turkish & TSL \\
& & $\mathrm{N}(\%)$ & $\mathrm{N}(\%)$ \\
\hline \multirow{2}{*}{ S2Downgrader } & Politeness marker & $3(12.5)$ & $5(21.7)$ \\
\cline { 2 - 4 } & Understater & $1(4.2)$ & $0(0)$ \\
\cline { 2 - 4 } & Subjectivizer & $1(4.2)$ & $0(0)$ \\
\cline { 2 - 4 } & Downtoner & $4(16.7)$ & $3(13)$ \\
\cline { 2 - 4 } & Cajoler & $0(0)$ & $1(4.3)$ \\
\cline { 2 - 4 } & Appealer & $0(0)$ & $2(8.7)$ \\
\cline { 2 - 4 } & Conditional politeness & $1(4.2)$ & $0(34.8)$ \\
\cline { 2 - 4 } & Aspect & $4(16.7)$ & $3(13)$ \\
\cline { 2 - 4 } & Tense & $3(12.5)$ & $23(100)$ \\
\cline { 2 - 4 } & Conditional clause & $24(100)$ & \\
\hline Total & & &
\end{tabular}

$\left(\chi^{2}(9, N=78)=9.693, p>.05, p=.376\right)$

The distribution of downgraders in situation 2 does not result in a significant difference, $\chi^{2}(9, N=78)=9.693, p>$.05. Table 14 outlines this finding. 
Table 15: Distribution of downgraders in situation 3

\begin{tabular}{|c|c|c|c|}
\hline & & & \\
\hline & & Turkish & TSL \\
\hline & & N (\%) & $\mathrm{N}(\%)$ \\
\hline S3Downgrader & Politeness marker & $3(8.8)$ & $7(16.3)$ \\
\hline & Understater & $0(0)$ & $4(9.3)$ \\
\hline & Lack of intent & $5(14.7)$ & $5(11.6)$ \\
\hline & Subjectivizer & $3(8.8)$ & $5(11.6)$ \\
\hline & Appealer & $0(0)$ & $1(2.3)$ \\
\hline & Word choice & $2(5.9)$ & $5(11.6)$ \\
\hline & Interrogative & $0(0)$ & $1(2.3)$ \\
\hline & Verbal noun & $5(14.7)$ & $0(0)$ \\
\hline & Conditional politeness & $9(26.5)$ & $2(4.7)$ \\
\hline & Aspect & $6(17.6)$ & $11(25.6)$ \\
\hline & Conditional clause & $1(2.9)$ & $2(4.7)$ \\
\hline Total & $05, \mathrm{p}=.031)$ & $34(100)$ & $43(100)$ \\
\hline
\end{tabular}

According to Table 15, which shows the frequency of downgraders used by the two groups of students in situation 3 , there is a significant difference in the use of downgraders, $\chi^{2}(10, N=78)=19.864, p<.05$.

Table 16: Distribution of downgraders in situation 4

\begin{tabular}{|c|c|c|c|}
\hline & & \multicolumn{2}{|c|}{ Group } \\
\hline & & Turkish & TSL \\
\hline & & N (\%) & N (\%) \\
\hline \multirow[t]{13}{*}{ S4Downgrader } & Politeness marker & $7(13.5)$ & $12(23.1)$ \\
\hline & Understater & $8(15.4)$ & $7(13.5)$ \\
\hline & Lack of intent & $1(1.9)$ & $3(5.8)$ \\
\hline & Subjectivizer & $5(9.6)$ & $3(5.8)$ \\
\hline & Downtoner & $0(0)$ & $2(3.8)$ \\
\hline & Cajoler & $0(0)$ & $1(1.9)$ \\
\hline & Appealer & $0(0)$ & $1(1.9)$ \\
\hline & Word choice & $1(1.9)$ & $6(11.5)$ \\
\hline & Verbal noun & $1(1.9)$ & $1(1.9)$ \\
\hline & Conditional politeness & $9(17.3)$ & $2(3.8)$ \\
\hline & Aspect & $14(16.9)$ & $10(19.2)$ \\
\hline & Tense & $3(5.8)$ & $0(0)$ \\
\hline & Conditional clause & $3(5.8)$ & $4(7.7)$ \\
\hline Total & & $52(100)$ & $52(100)$ \\
\hline
\end{tabular}


Table 16 reveals that there is no significant difference between the two groups in their use of downgraders in situation $4, \chi^{2}(12, N=78)=18.718, p>.05$. Table 16 outlines this finding.

Table 17: T-test results for situation 1

\begin{tabular}{|c|c|c|c|c|c|c|c|}
\hline & Group & $\mathrm{N}$ & Mean & Std. Deviation & $\mathrm{df}$ & $\mathrm{t}$ & Sig. \\
\hline & Turkish & 45 & 16.82 & 5.536 & & & \\
\hline \multirow[t]{3}{*}{ S1Length } & & & & & 76 & -2.079 & $.041^{*}$ \\
\hline & TSL & 33 & 19.91 & 7.584 & & & \\
\hline & Turkish & 45 & 3.16 & 1.186 & & & \\
\hline \multirow[t]{3}{*}{ S1NumTot } & & & & & 76 & -2.589 & $.012 *$ \\
\hline & TSL & 33 & 4.00 & 1.696 & & & \\
\hline & Turkish & 45 & 1.09 & .288 & & & \\
\hline \multirow[t]{3}{*}{ S1NumHA } & & & & & 76 & .1 .037 & .303 \\
\hline & TSL & 33 & 1.03 & .174 & & & \\
\hline & Turkish & 45 & 1.47 & .726 & & & \\
\hline \multirow[t]{3}{*}{ S1NumSup } & & & & & 76 & -1.595 & .115 \\
\hline & TSL & 33 & 1.79 & 1.053 & & & \\
\hline & Turkish & 45 & .47 & .625 & & & \\
\hline \multirow[t]{2}{*}{ S1NumDown } & & & & & 76 & -1.259 & .212 \\
\hline & TSL & 33 & .67 & .777 & & & \\
\hline
\end{tabular}

According to the results of the $t$-test analyses shown in table 17, the requests provided by the TSL group $(M=19.91, S D=7.58)$ are longer than those of the Turkish group $(M=16.82, S D=5.53)$ in situation 1 . This difference is significant, $t(76)=-2.079, p=.041, p<.05$. As is seen in the results of the $t$-test analyses, the TSL and the Turkish groups differed in one of the four comparisons in strategy numbers. The TSL group $(M=4.00, S D=1.69)$ used more strategies than the Turkish group $(M=3.16, S D=1.18)$, which is significant, $t(76)=-2.589, p=.012$, $p<.05$. The other categories of comparison, namely number of head acts, number of supportive moves and number of downgraders, do not result in significant difference.

Table 18: T-test results for situation 2

\begin{tabular}{llllllll}
\hline & Program & $\mathrm{N}$ & Mean & Std. Deviation & $\mathrm{df}$ & $\mathrm{t}$ & Sig. \\
\hline \multirow{3}{*}{ S2Length } & Turkish & 45 & 16.24 & 8.858 & & & \\
& & & & & 76 & -1.879 & .267 \\
& TSL & 33 & 19.58 & 5.858 & & & \\
\hline
\end{tabular}




\begin{tabular}{|c|c|c|c|c|c|c|c|}
\hline & Turkish & 45 & 3.38 & 1.230 & & & \\
\hline \multirow[t]{3}{*}{ S2NumTot } & & & & & 76 & -2.087 & .930 \\
\hline & TSL & 33 & 4.00 & 1.392 & & & \\
\hline & Turkish & 45 & 1.07 & .252 & & & \\
\hline \multirow[t]{3}{*}{ S2NumHA } & & & & & 76 & .107 & .832 \\
\hline & TSL & 33 & 1.06 & .242 & & & \\
\hline & Turkish & 45 & 1.20 & .588 & & & \\
\hline \multirow[t]{3}{*}{ S2NumSup } & & & & & 76 & -2.209 & $.009^{*}$ \\
\hline & TSL & 33 & 1.55 & .794 & & & \\
\hline & Turkish & 45 & .53 & .625 & & & \\
\hline \multirow[t]{2}{*}{ S2NumDown } & & & & & 76 & -1.361 & $.019 *$ \\
\hline & TSL & 33 & .76 & .830 & & & \\
\hline
\end{tabular}

According to table 18, in situation 2, the TSL group and the Turkish group differ significantly in the number of supportive moves $(t(76)=-2.209, p=.009, p<.05)$ and the number of downgraders $(t(76)=-1.351, p=.019, p<.05)$. The other categories of comparison do not result in significant difference.

Table 19: T-test results for situation 3

\begin{tabular}{|c|c|c|c|c|c|c|c|}
\hline & Program & $\mathrm{N}$ & Mean & Std. Deviation & $\mathrm{df}$ & $\mathrm{t}$ & Sig. \\
\hline & Turkish & 45 & 18.33 & 7.465 & & & \\
\hline \multirow[t]{3}{*}{ S3Length } & & & & & 76 & -3.028 & .540 \\
\hline & TSL & 33 & 23.61 & 7.778 & & & \\
\hline & Turkish & 45 & 5.04 & 1.492 & & & \\
\hline \multirow[t]{3}{*}{ S3NumTot } & & & & & 76 & -3.571 & .547 \\
\hline & TSL & 33 & 6.18 & 1.236 & & & \\
\hline & Turkish & 45 & .98 & .149 & & & \\
\hline \multirow[t]{3}{*}{ S3NumHA } & & & & & 76 & -.855 & .084 \\
\hline & TSL & 33 & 1.00 & .000 & & & \\
\hline & Turkish & 45 & 2.20 & .815 & & & \\
\hline \multirow[t]{3}{*}{ S3NumSup } & & & & & 76 & -1.072 & .152 \\
\hline & TSL & 33 & 2.42 & 1.032 & & & \\
\hline & Turkish & 45 & .76 & .773 & & & \\
\hline \multirow[t]{2}{*}{ S3NumDown } & & & & & 76 & -2.908 & .370 \\
\hline & TSL & 33 & 1.30 & .883 & & & \\
\hline
\end{tabular}

Table 19 shows that the two groups do not differ significantly in any of the comparisons in situation 3 although the TSL group seem to use more words and more strategies, however, this does not result in a significant difference. 
Table 20: T-test results for situation 4

\begin{tabular}{|c|c|c|c|c|c|c|c|}
\hline & Program & $\mathrm{N}$ & Mean & Std. Deviation & $\mathrm{df}$ & $\mathrm{t}$ & Sig. \\
\hline & Turkish & 45 & 16.02 & 7.319 & & & \\
\hline \multirow[t]{3}{*}{ S4Length } & & & & & 76 & -3.710 & .421 \\
\hline & TSL & 33 & 22.64 & 8.370 & & & \\
\hline & Turkish & 45 & 4.76 & 1.510 & & & \\
\hline \multirow[t]{3}{*}{ S4NumTot } & & & & & 76 & -3.296 & .751 \\
\hline & TSL & 33 & 6.00 & 1.820 & & & \\
\hline & Turkish & 45 & 1.09 & .288 & & & \\
\hline \multirow[t]{3}{*}{ S4NumHA } & & & & & 76 & .458 & .358 \\
\hline & TSL & 33 & 1.06 & .242 & & & \\
\hline & Turkish & 45 & 1.38 & .716 & & & \\
\hline \multirow[t]{3}{*}{ S4NumSup } & & & & & 76 & -3.520 & .182 \\
\hline & TSL & 33 & 2.06 & .998 & & & \\
\hline & Turkish & 45 & 1.16 & .903 & & & \\
\hline \multirow[t]{2}{*}{ S4NumDown } & & & & & 76 & -2.030 & .826 \\
\hline & TSL & 33 & 1.58 & .902 & & & \\
\hline
\end{tabular}

Again in situation 4, the two groups do not differ significantly in any of the comparisons. According to the mean values, the TSL group seems to use more words and more strategies, but these differences are not large enough to create significant differences.

\section{CONCLUSION}

The study reveals that there are differences between the two groups, namely Turkish native speakers and learners of Turkish as a second language, in utilizing request strategies. However, it is also observed that the differences are not drastic. When head act strategies are looked into, two groups differentiated only in one situation (situation 3). Again with downgrader strategies, the two groups differed only in one situation (situation 3). The major difference occurred in strategy selection with supportive moves. The groups differed in three of the four situations. The situation that did not result in a significant difference is situation 1 . When the make-up of the requests (i.e. length in words and the average number of strategies used in each category) is investigated, it could be argued that the differences are minimal. When the two groups are compared based on the length of their requests, significant difference is observed only in situation 1. Again in total number of strategies used in each situation, the two groups differed significantly only in situation 1 . The groups did not differ in situation 2 through 4 in the length and total number of 
strategies employed. When head act strategy numbers are looked into, no significant difference is observed in any of the situations, which is expected as request speech acts are usually single-headed.

The rest of the differences are observed in the average number of supportive moves and the average number of downgraders and these differences are only observed in situation 2. The two groups did not differ in situation 1, situation 3 and situation 4 . Table 21 outlines these findings.

Table 21: Summary of probability values

\begin{tabular}{crrrr}
\hline & Situation 1 & Situation 2 & Situation 3 & Situation 4 \\
\hline Head acts & .626 & .236 & $.027^{*}$ & .540 \\
Supportive moves & .094 & $.029^{*}$ & $.006^{*}$ & $.025^{*}$ \\
Downgraders & .056 & .376 & $.031^{*}$ & .096 \\
Length & $.041^{*}$ & .267 & .540 & .421 \\
\hline Total number of str. & $.012^{*}$ & .930 & .547 & .751 \\
Num. of head acts & .303 & .832 & .084 & .358 \\
Num. of sup. moves & .115 & $.009 *$ & .152 & .182 \\
Num. of downgraders & .212 & $.019 *$ & .370 & .826 \\
\hline
\end{tabular}

The study is significant as it provides some initial data about interlanguage pragmatics in Turkish as well as being one of the initial studies outlining request speech act in Turkish. However, the study also has some limitations. First of all, the current study is not developmental in that it does not compare the results with earlier data (e.g. upon learners' arrival in Turkey) or have a cross-sectional design. Thus, it does not show developmental patterns or features. Second of all, since the data does not include L1 data of the TSL group, the study does not control for crosslinguistic transfer. To overcome transfer effect, however, the participants with different linguistic background are employed. The third limitation is related to the second one. Since learners come with diverse linguistic backgrounds, control of confounding variables was limited. However, in spite of its limitations, this study is a significant step in describing learners' interlanguage pragmatics of Turkish as well as request speech acts used by both native and nonnative speakers of Turkish.

\section{References}

Austin, J. L.(1962). How to do things with words. Oxford: Oxford University Press.

Bardovi-Harlig, K. (1999). Exploting the interlanguage of interlanguage pragmatics: A research agenda for acquisitional pragmatics. Language Learning, 49(4), 677-713. 
Barron, A. (2003). Acquisition in interlanguage pragmatics: Learning how to do things with

words in a study abroad context. Philadelphia, PA, USA: John Benjamins Publishing Company.

Blum-Kulka, S. (1982). Learning to say what you mean in a second language: A study of speech act performance of learners of Hebrew as a second language. Applied Linguistics, 3, 29-59.

Blum-Kulka, S., Danet, B. \& Gherson, R. (1985). The language of requesting in Israeli society. In J. P.

Forgas (Ed.), Language and Social Situations (pp. 113-139). New York, NY: SpringerVerlag

Blum-Kulka, S., House, J. \& Kasper, G. (Eds.). (1989). Cross-Cultural Pragmatics: Requests and Apologies. Norwood, NJ: Ablex.

Brown, P. \& Levinson, S. (1987). Politeness: Some Universals in Language Usage. Cambridge: Cambridge University Press.

Byon, A. S. (2004). Sociopragmatic analysis of Korean requests: Pedagogical settings. Journal of Pragmatics, 36, 1673-1704.

Byon, A. S. (2006). The role of linguistic indirectness and honorifics in achieving linguistic politeness in Korean requests. Journal of Politeness Research, 2, 247-276.

Cohen, A. (2004). Assessing Speech Acts in a Second Language. In D. Boxer \& A. Cohen (Eds.), Studying Speaking to Inform Second Language Learning (pp. 302-327). Clevedon: Multilingual Matters Ltd.

Cohen, A. D. \& Olshtain, E. (1981). Developing a measure of socio-cultural competence: The case of apology. Language Learning, 31(1), 113-134.

Félix-Brasdefer, J.C. (2009). Pragmatic variation across Spanish(es): Requesting in Mexican, Costa Rican, and Dominican Spanish. Intercultural Pragmatics, 6(4), 473-515.

Fukushima, S. (1996). Request strategies in British English and Japanese. Language Sciences, 18(3-4), 671-188.

García, C. (1993). Making a request and responding to it: A case study of Peruvian Spanish speakers. Journal of Pragmatics, 19(2), 127-152.

Grice, H. P. (1975). Logic and Conversation. In P. Cole \& J. Morgan (Eds.), Syntax and Semantics, Vol. 3, Speech Acts (pp. 41-58). New York: Academic Press.

Hong, W. (1996). An empirical study of Chinese request strategies. International Journal of the Sociology of Language, 122, 127-138.

Hudson, T., Detmer, E. and Brown, J. D. (1995). Developing prototypic measures of cross- 
cultural pragmatics. Honolulu, HI: University of Hawai'i Press.

Kanik, M. (2010). Does Instruction in L2 Have an Impact on L1 Pragmalinguistic Use? In D. Köksal, İ. H. Erten, E.Z. Topkaya \& A. Yavuz (Eds.), The $6^{\text {th }}$ International ELT Research Conference Proceedings: Current Trends in SLA Research and Language Teaching. Canakkale: Canakkale Onsekiz Mart University.

Kasper, G. \& Dahl, M. (1991). Research methods in interlanguage pragmatics. SSLA, 13, 215-247.

Kasper, G. \& Rose, K. (1999). Pragmatics and SLA. Annual Review of Applied Linguistics, 19, 81-104.

Kasper, G. \& Schmidt, R. (1996). Developmental issues in interlanguage pragmatics. SSLA, 18, 149-169.

Marti, L. (2006). Indirectness and politeness in Turkish-German bilingual and Turkish monolingual requests. Journal of Pragmatics, 38, 1836-1869.

Rose, K. (2000). An exploratory cross-sectional study of interlanguage pragmatic development. SSLA, 22, 27-67.

Rue, Y. J., Zhang, G. \& Shin, K. (2007). Request strategies in Korean. Proceedings of the $5^{\text {th }}$ Biannual

Korean Studies Association of Australasia Conference,112-119. Retrieved from http://www.ksaa.net/proceedings/KSAA05-2007.pdf.

Searle, J. R. (1969). Speech Acts: An Essay in the Philosophy of Language. Cambridge: Cambridge University Press.

Searle, J. R. (1979). Expression and Meaning: Studies in the Theory of Speech Acts. Cambridge: Cambridge University Press.

Vellenga, H. (2004). Learning pragmatics from ESL and EFL textbooks: How likely? TESL$E J, 8(2)$, Retrieved from http://tesl-ej.org/ej30/a3.html 